\title{
JELLEGZETES CSAPÁGYFREKVENCIÁK VIZSGÁLATA
}

\author{
Tóth Dániel \\ tanársegéd, Miskolci Egyetem \\ Szerszámgépészeti és Mechatronikai Intézet, Szerszámgépek Intézeti Tanszéke \\ 3515 Miskolc, Miskolc-Egyetemváros, e-mail: toth.daniel@uni-miskolc.hu
}

\begin{abstract}
Absztrakt
A rezgések spektrum-, illetve frekvenciaanalizise nemcsak népszerü, hanem a jelenlegi leghatékonyabb gépállapot-felmérö eszköz is egyben. A rezgésdiagnosztikai vizsgálatok során a csapágyaknak, mint az egyik leggyakoribb gépelemeknek, mindenütt kiemelt szerepet játszanak. Jelen cikk a jellegzetes csapágyfrekvenciákkal foglalkozik.
\end{abstract}

Kulcsszavak: csapágyak, frekvencia, rezgésdiagnosztika

\section{Abstract}

The spectral or frequency analysis of vibrations is not only popular, but also the most efficient machine condition assessment tool. Bearings, as one of the most common machine components, play an important role during vibration diagnostic tests. The following paper deals with investigation of typical frequencies of bearings.

Keywords: bearings, frequency, vibration diagnostic

\section{Bevezetés}

A gépészmérnöki gyakorlatban mérhető géprezgések összetett jellegüek, mivel a mérőhelyen (például egy csapágyházon) egyszerre vannak jelen a tengelybeállításból, a kiegyensúlyozatlanságból, a csapágyhibából és más gépelemek egyéb problémáiból származó - eltérő amplitúdójú és frekvenciájú rezgések. Ha a mért jelben előforduló frekvenciákra vagyunk kíváncsiak, akkor a jelet elemi szinuszos alkotóelemeire (alaprezgéseire) kell felbontani, vagyis frekvenciaanalízist (más néven spektrumanalízist) kell végezni. Az egyes gépelemek hibái pontosan felderíthetők a rezgések spektrumanalízise révén, valamint eldönthető az is, hogy beállítási vagy kiegyensúlyozási hiba van-e jelen. A csapágyhibák elemzése esetén ez a módszer képes arra is, hogy külön kimutassa a kosár, a gördülőtest vagy a belső és a külső gyürü sérülését. A géprezgések spektrumanalízisének köszönhetően, már a javítások előtt tudni lehet, hogy mi a teendő. Ezzel jelentős megtakarítás érhető el a munkaidő és az alkatrészek vonatkozásában, ráadásul a javítás során a nem annyira feltünő hibák kijavítása is egyértelmü. Nagyon pontosan és gyorsan ellenőrizhető a javítások sikeressége is, a javítás előtti és az újbóli beüzemeléskor végzett mérések spektrumainak összehasonlításával. Csökkenő karbantartási költségek mellett, az így javított és ellenőrzött gépek megbízhatósága nagymértékben növekszik [1].

\section{Jellegzetes csapágyfrekvenciák}

A csapágyak azzal az alapvető mechanikai tulajdonsággal rendelkeznek, hogy leginkább egy-egy bizonyos frekvencián képesek adott irányokban rezgést végezni. Ezek a jellegzetes frekvenciák a felvett 
rezgésjel spektrumanalízisével beazonosíthatók, és az aktuális csapágyfordulatszám figyelembevételével hozzárendelhetők csapágyalkatrészekhez. E jellegzetes frekvenciákon kibocsájtott rezgési energia a defektus megjelenése és továbbfejlődése esetén megváltozik és ez a spektrumban is megjelenik. A sérült csapágyalkatrészek rezgéseket gerjesztenek. Ezek frekvenciája attól függ, hogy a sérülés a csapágy mely alkatrészén következett be. A csapágy bizonyos alapvető geometriai méreteinek ismeretében ezek a csapágy-hibafrekvenciák kiszámíthatók, ezzel mintegy alapot teremtve a müszeres vizsgálatnak. A számításhoz az alábbi adatokat kell ismerni [2]:

- hatásszög: $\vartheta$,

- görgők száma: Z,

- tengely fordulatszáma: N,

- golyók vagy görgők gördülőpályájának átmérője: øD,

- görgők vagy golyók átméröje ød.

A hatásszög a golyók (vagy görgők) és a futópálya érintkezési pontjain átmenő, a csapágy tengelysíkjában fekvő egyenes - amely mentén a terhelés az egyik futópályáról a másikra átadódik - és a csapágy tengelyére merőleges egyenes által bezárt szög. Ezek alapján az 1. táblázatban megadott csapágyfrekvenciák számíthatók.

1. táblázat. Csapágyfrekvenciák jelölései

\begin{tabular}{|c|c|c|}
\hline Frekvencia neve & $\begin{array}{c}\text { Általános } \\
\text { rövidítés }\end{array}$ & $\begin{array}{c}\text { Speciális } \\
\text { jelölés }\end{array}$ \\
\hline Belső gyürü frekvencia & BPFI (Ball Pass Frequency - Inner race) & $\mathrm{I}$ \\
\hline Gördülötest frekvencia & BSF (Ball Spin Frequency), & $\mathrm{G}$ \\
\hline Kosárfrekvencia & FTF (Fundamental Train Frequency) & $\mathrm{K}$ \\
\hline Külső gyürü frekvencia & BPFO (Ball Pass Frequency - Outer race) & $\mathrm{O}$ \\
\hline
\end{tabular}

A külső gyürű sérülése az egyik leggyakoribb csapágyhiba, mivel általában a külső gyürü áll, és a terhelés (például a tömeg) a görgőkön vagy a golyókon keresztül a külső gyürü mindig ugyanazon pontjára hat. A csapágyfrekvenciák számításánál olyan gördülőcsapágyak lettek figyelembe véve, amelyek esetén a külső gyürü áll, a belső gyürü pedig forog. Ilyenkor a fenti jellemzők az alábbiak szerint számítandók [2]:

$$
\begin{aligned}
& B P F O=\frac{Z}{2} \frac{N}{60}\left(1-\frac{d}{D} \cos \vartheta\right) ; \\
& B P F I=\frac{Z}{2} \frac{N}{60}\left(1+\frac{d}{D} \cos \vartheta\right) ; \\
& B S F=\frac{D}{2 d} \frac{N}{60}\left[1-\left(\frac{d}{D} \cos \vartheta\right)^{2}\right] ; \\
& F T F=\frac{N}{2 \times 60}\left(1-\frac{d}{D} \cos \vartheta\right) .
\end{aligned}
$$




\section{Csapágyfrekvenciák társítása tönkremenetelekkel}

A csapágyak rezgéstani szempontból igen bonyolult mechanikai rendszerek. Általában hajlamosak a berezgésre ezért a keltett rezgések, valamint a mechanikai jellemzők közötti összefüggések feltárása nehézséget okoz. Egyes rezgések az alkatrészek önrezgései. Ezek a gerjesztés frekvenciájától függő amplitúdóval, de viszonylag állandó frekvenciával jelentkeznek, jelenlétükre mindig lehet számítani. A sajátfrekvenciákkal egyidejüleg megjelennek azok a rezgések is, amelyeket a periodikus gerjesztések idéznek elő, például valamelyik gyürü ütéséből származó rezgés. A rezgések zöme azonban a gördülöpályák és a gördülőtestek alak- és felülethibáiból eredeztethető. A csapágyak rezgéseinek vizsgálatakor sokszor keresik a csapágy alak- és felülethibái, valamint a keltett rezgések közötti tapasztalati összefüggéseket [3]. Fontos ez a csapágy fenntartása, de a csapággyártás szempontjából is, ugyanis a gyártó cég így döntheti el, hogy az alkatrészek közül melyek azok, amelyek minőségének a javításával csendesebb, kisebb rezgést keltő csapágyak gyárthatók. A csapágy rezgéserőssége függ a csapágyak radiális hézagától, a gördülőtest és a külső és belső gördülőpálya alakhibájától (excentricitásától, ovalitástól, sokszögüségtől), hullámosságtól és felületi érdességtől. A csapágy elhasználódása folyamán a felületi érdesség az eredeti érdességnek a százszorosára is növekedhet. Ilyenkor a gördülöpályák felületi érdességének és hullámosságának a növekedése együtt növeli a csapágy rezgéseit. A tájékoztató összefüggések ismerete azért hasznos, mert a csapágy gördülő pályái a használat során a kopás következtében berágódnak, kipikkelyesednek, vagyis hullámosságai, érdességei megváltoznak. Mindezek a változások az elhasználódás során a csapágyak által keltett rezgéseket növelik [4]. A rezgésspektrumok elemzése további szorosabb összefüggések feltárására ad lehetőséget. A csapágysérülések esetén fellépő periodikus ütésgerjesztések mindig az ütésfrekvencia (hibafrekvenciák) egész számú többszöröseit eredményezik. Tisztán szinuszos gerjesztés (kiegyensúlyozatlanság) esetén pedig csak a gerjesztés alapfrekvenciája jelenik meg a spektrumban [5]. Nem ritkán javítások után megfigyelhető, hogy előfeszítetten beszerelt csapágyak szinuszos erőlefutást produkálnak a körülfordulás során. Ez szíjhajtások esetén különösen megfigyelhető. Kis csapágyhézag esetén a külsőgyürü hibafrekvenciája a domináns. Ekkor a kosár az alapvetỏen megterhelt csapágyalkatrész. Ennek oka, hogy a deformáció következtében a kosár kényszeríti át a gördülőelemeket a legkisebb hézagú résen. Mivel a kosárnak ezt mindegyik görgővel el kell végeznie, ezért a spektrumban a kosárfrekvencia és görgőszám szorzata jelenik meg, amely nem más, mint a külsőgyürü frekvencia. Amennyiben a spektrumban jellemzően a hibafrekvenciák igen magas felharmonikusai jelennek meg, akkor ez azt jelenti, hogy kicsi, éles sérülések fordulnak elő a futófelületek mentén. Szennyeződések ugyanezt produkálják, ám ekkor az alap frekvenciaértékek hiányoznak a spektrumból. Amennyiben az alapfrekvenciák mellett azok alacsony felharmonikusai is jelen vannak, úgy ez nagy és mély csapágysérülésekkel magyarázható [6]. Igen rossz állapotú csapágyak esetén a csapágyhiba frekvenciák rezonancia gerjesztések alakjában jelennek meg.

\section{Csapágyfrekvenciák vizsgálata spektrumanalízissel}

A hibafrekvenciák egész számú többszörösei is megjelenhetnek a spektrumokban, fordulatszám frekvencia nagyságú oldalsávokkal, ennek okán rezgésdiagnosztikai vizsgálatokat végeztem egy FAG 6303-2RSR típusú golyóscsapágyon. A vizsgált golyóscsapágy forgási frekvenciája 22,85 [Hz]. Mivel a legtöbb gép tipikus (mechanikai eredetü) hibája a forgásfrekvenciához (vagy annak egészszámú többszöröseihez) kötődik, ezért terjedt el a spektrumok frekvenciatengelyének skálázása fordulatszámegységekben is. Ilyenkor a spektrum-diagram vízszintes frekvenciatengelyei kerülnek átskálázásra (a csapágy forgási frekvenciájával lesznek elosztva), melynek eredményeként dimenziótlanított frekven- 
ciát kapható, ahol „1” a forgási frekvenciának felel meg. Ezt egyes irodalmak order-számnak is nevezik [7]. A gördülőcsapágyak jellegzetes hibafrekvenciái is a fordulatszám lineáris függvényei. Az 1. ábra a csapágy korai életszakaszában megjelenő csapágyhibákat mutatja, a 2. ábrán látható a csapágy későbbi életszakaszában beazonosított hibafrekvenciák. A hibák azonosítási kódjai az 1. táblázatban jelölt rövidítések szerint valósultak meg.

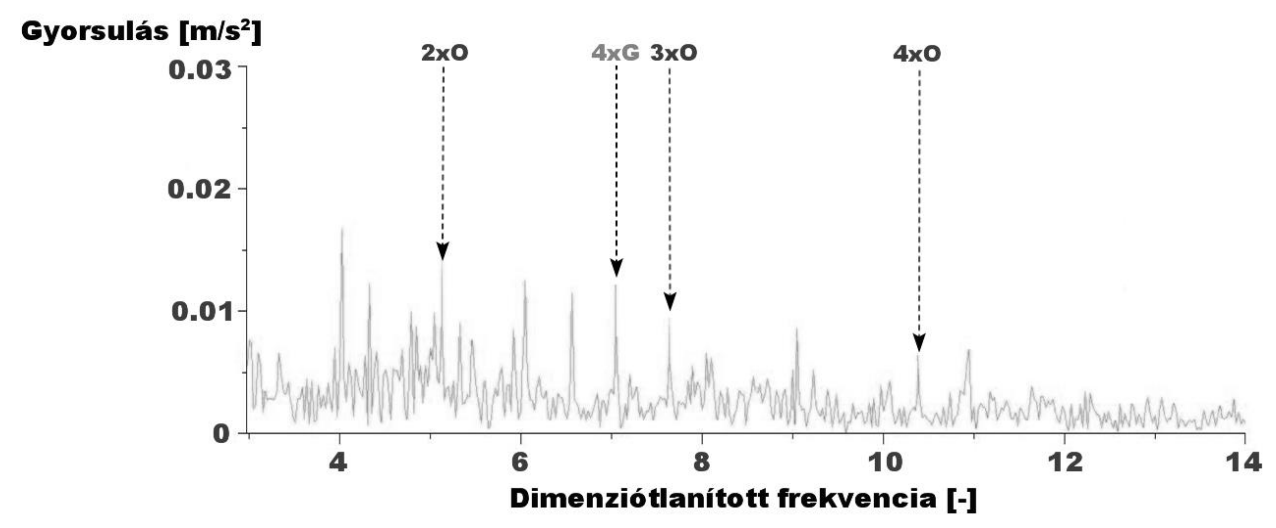

1. ábra. Hibafrekvenciák a csapágy korai életszakaszából

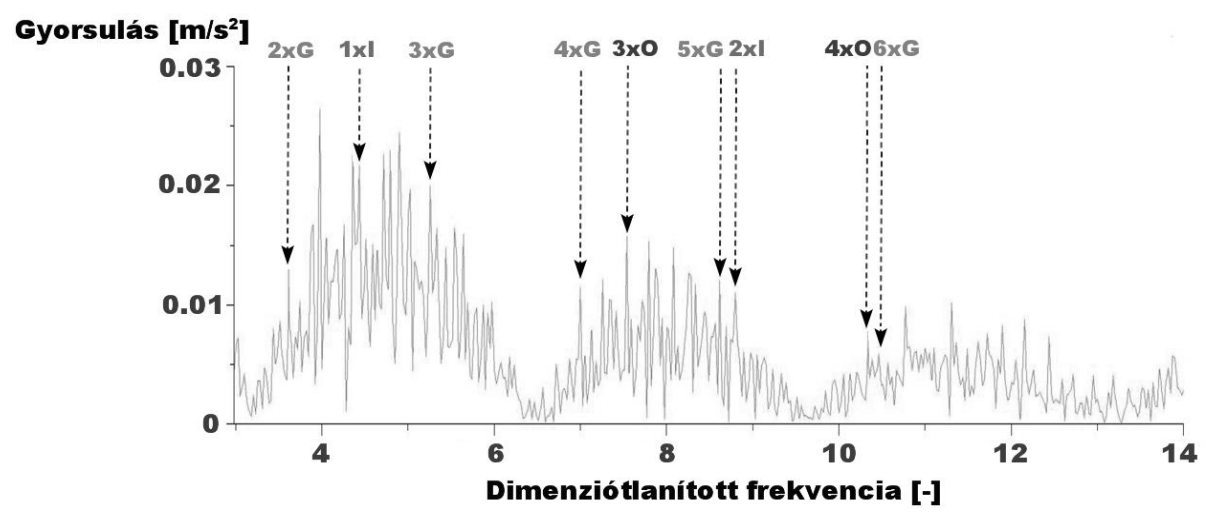

2. ábra. Hibafrekvenciák a csapágy késői életszakaszából

Az ábrák alapján látható, hogy a csapágy korai életszakaszában jelentősen kevesebb csapágyhiba felharmonikus jelent meg, és ezek értékei is alacsonyabbak, mint a csapágy későbbi életszakaszában lévők.

\section{5. Összefoglalás}

Jelen cikk keretei között megvizsgáltam a jellegzetes csapágyfrekvenciákat, elemeztem a csapágyfrekvenciák kapcsolatát a tönkremenetellel, továbbá tanulmányoztam egy golyóscsapágy hibafrekvenciáit spektrumanalízis segítségével. A rezgésdiagnosztikai módszerek hatékonyan alkalmazhatók a csapágyállapot megítélésére, valamint a spektrumanalízis nyújtotta lehetőségekre támaszkodva hasznos információkat kaphatunk a rezgés jellegéről, a hibák csapágyon belüli elhelyezkedéséröl, és azok relatív nagyságáról is. 


\section{Köszönetnyilvánítás}

A cikkben ismertetett kutató munka az EFOP-3.6.1-16-2016-00011 jelü „Fiatalodó és Megújuló Egyetem - Innovatív Tudásváros - a Miskolci Egyetem intelligens szakosodást szolgáló intézményi fejlesztése" projekt részeként - a Széchenyi 2020 keretében - az Európai Unió támogatásával, az Európai Szociális Alap társfinanszírozásával valósul meg.

\section{Irodalom}

[1] Tóth, S. G., Takács, Gy., Tóth, D.: Új generációs termékek élettartam tesztelő berendezésének kifejlesztése. Hazai és külföldi modellek a projektoktatásban, Budapest, 2018.

[2] Tóth, L.: Tranziens és kváziperiodikus folyamatok analizise az idö-frekvencia tartományban. PhD értekezés, Miskolc, 2011.

[3] Hegedüs, Gy., Barak, A., Barna, B., Demeter, P., Simon, G., Szilágyi, A., Takács, Gy.: Development of analyzing equipment of the remanent lifetime on roller bearings, MicroCAD 2010: XXIV. microCad International Scientific Conference: Section L: Machine and structure design, Miskolc, Hungary: University of Miskolc, pp. 47-52. 2010.

[4] Patel, J., Patel, V., Patel, A.: Fault Diagnostics of Rolling Bearing based on Improve Time and Frequency Domain Features using Artificial Neural Networks. IJSRD, Vol. 1, Issue 4, 2013.

[5] Patidar, S., Soni, P. K.: An Overview on Vibration Analysis Techniques for the Diagnosis of Rolling Element Bearing Faults. IJETT, May 2013.

[6] Kharche, P. P., Kshirsagar, S. V.: Review of Fault Detection in Rolling Element Bearing. IJIRAE, Vol. 1 Issue 5, June 2014.

[7] Dömötör, F.: Rezgésdiagnosztika I. Dunaújváros, 2008. 